\title{
Egy világméretű sportesemény, a 2017 Vizes Világbajnokság néhány társadalmi aspektusa a jövő managereinek szemszögéből a felkészülési időszakban
}

\author{
Á. BENE, M. MóRÉ \\ Debreceni Egyetem, Ihrig Károly Gazdálkodás-, és Szervezéstudományok Doktori Iskola, Egészségügyi Kar \\ Szociális és Társadalomtudományi Intézet, beneagi@yahoo.com \\ Debreceni Egyetem, Egészségügyi Kar, Szociális és Társadalomtudományi Intézet
}

Absztrakt. A világ egyik legnagyobb sportrendezvényét a 2017-es Vizes Világbajnokságot és Masters Világbajnokságot Magyarországon rendezik. Jelen tanulmány a mega sportrendezvény társadalmi hatásait tárgyalja, és néhány hangsúlyos befolyásoló tényezôt vesz számba. A szerzők a nyári kezdés elôtt 6 hónappal, a felkészülési idôszakban vizsgálták a jövő managereinek vélekedéseit a feltárt társadalmi hatásokkal és az azonosított társadalmi és sportági befolyásoló tényezőkkel összefüggésben. Az empirikus kutatás helyszíne az ország legnagyobb hallgatói létszámmal bíró felsőoktatási intézménye a Debreceni Egyetem volt.

Abstract. Hungary hosts the 2017 FINA World Championships and Master's Championships, one of the world's largest sport event. Besides exploring the influential factors behind the potential effectivity, this study aims to identify social effects related to the event. Students in higher education today are the next generation of managers and company owners, therefore their attitudes and opinions will be determinative in terms of the decision-making. The empirical research took place in the University of Debrecen, the most populouses University of Hungary, 6 month before the official opening ceremony of the Championships.

\section{Bevezetés}

Magyarország 2013-ban először pályázott a világ harmadik legnagyobb sporteseményének, a FINA (Fédération Internationale de Natation, Nemzetközi Úszószövetség) Világbajnokság (VB) megrendezésének jogáért és a sikeres kandidálás eredményeként 2021-ben Budapest adhatott volna otthont a vizes sportok, - az úszás, a toronyugrás és a vízilabda, nemzetközi viadalának. 2015 márciusában a mexikói Guadalajara visszalépett a 2017-es világbajnokság lebonyolításától, helyette Magyarország vállalta a megrendezést. Számtalan Európa Bajnoki vetélkedés (egyebek mellett az 1926-os, a 2006-os és 2010-es úszó EB) megszervezése után ez lesz a legjelentősebb világverseny hazánkban.

A modern társadalomkutatásban egyre nagyobb jelentőséget kap annak vizsgálata, milyen hatással van a sport a társadalmi-gazdasági folyamatokra [1, 2, 3, 7, 11]. A leginkább elfogadott vélekedés szerint a sport javítja az állampolgárok jólétét, megerősíti a társadalmi értékeket [7, 16], elősegíti 
különböző társadalmi csoportok beilleszkedését és a felfelé irányuló mobilitás egyik fontos csatornája az egyének számára [13]. Magyarország 2007-ben elfogadott Nemzeti Sportstratégiájában visszaköszönnek ezek a gondolatok, kiegészítve azzal, hogy a nemzetközi eredmények hozzájárulhatnak egy nemzet önbecsüléséhez, ami erősíti a társadalmi kohéziót[16]. Ez utóbbi gondolat megnyilvánulása, a stratégiai célok elérésnek egyik eszköze lehet egy világverseny megrendezése, amely a nemzetek versengésének egyik fontos, szimbolikus terepe. Egy nemzetközi sportrendezvény értékei között megtaláljuk a tolerancia, az együttműködés, a multikulturalizmus, a csapatjáték, a szolidaritás elveit, amelyek a nemzeti identitás, büszkeség alapjait adhatják [7, 11, 19]. A Rendezvény nagy publicitása lehetőséget ad az ország, a helyszínek bemutatkozására. A kulturális és épített örökség elemeit a résztvevők és látogatók közvetlenül, míg a média közvetítések nézői közvetve ismerik meg.

\section{Nemzetközi sportrendezvények hatásai}

\subsection{Gazdasági és társadalmi hatások}

A sportgazdaságtan legfontosabb megjelenési formái ma, a nemzetközi sportrendezvények. A sport központi termékét a különböző sportrendezvények jelentik. Egy-egy nemzetközi szintű sportrendezvény (olimpia, világbajnokság) sportgazdaságtani szempontból a sport összes piacára (fogyasztó piac, játékos piac, közvetítési jogok piaca, sportszponzori piac, merchandising piac) hatást gyakorol. Ezen túl hatást gyakorolnak a rendező ország / város gazdaságára is. A gazdasági és nem gazdasági jellegű hatások már a felkészülési időszakban is, a rendezvényt követően pedig rövid és hosszú távon egyaránt megjelennek. A nemzetközi sportrendezvények új fejlesztő erőt jelenthetnek a város/ ország életében [3, 19]. A hatások szerteágazóak, vizsgálatuk és elemzésük fókuszfüggő, a nemzetközi szakirodalom többféle csoportosítást is használ. A tervezési, előkészítési időszakban a legnagyobb hatást a létesítmény- és infrastruktúrafejlesztés jelenti. Ebben az esetben leginkább az építőipar bevételei, beruházásai és az ehhez kapcsolódó munkalehetőségek növekednek meg [2]. A rendezvények ideje alatt a közvetlen fogyasztás emelkedik meg, amely elsősorban a turizmusból és vendéglátásból származtatható, hiszen az esemény időtartalma alatt a városokba (országba) rengeteg sportoló, résztvevő és szurkoló érkezik. A közvetlen fogyasztás helyileg az adott városban és térségében továbbá nemzetközi szinten (támogató márkák termékeladása, légitársaságok) is növekedhet. Helyi szinten a közlekedésből, szálláshelyek kiadásából, vendéglátásból és a különböző a rendezvényhez kapcsolódó szolgáltatásból (biztonsági szolgálat, merchandise tárgyak értékesítése, reklámszolgáltatás értékesítése) állhat össze. Hosszú távon a rendezvényhez kapcsolódó fenntartható munkahelyek, a jól használható létesítmények, az infrastruktúra beruházások jelentik a konkrétan megfogható gazdasági hatásokat [2]. A turizmusból származó bevétel növekedés már a felkészülési időszakban is kimutatható, azonban számottevő hatása a Rendezvény utáni években lehet $[2,19]$.

A rendező ország lakosságát egy sportrendezvény aktívabb sportolásra ösztönzi, amely az egészségügyi költségek csökkenéséhez vezethet $[1,2,11,19]$. A sportolási hajlandóság növekedése révén az egyén számára a sport első sorban egészségfejlesztésre, kikapcsolódásra, illetve a munkavégző képesség helyreállítására nyújt lehetőséget [15, 16, 17]. 
A 2007-ben elfogadott XXI. Nemzeti Sportstratégiában [16] testet öltött célrendszer szerint a kormányzat kiemelt céljai:

Harmonikus társadalom - a közösségi kapcsolatok fejlesztése

- Közösségi kapcsolatok fejlesztésére, a szabadidő tartalmas eltöltésére lehetőséget nyújtó közösségi terek kialakítása.

- A baráti, társasági kapcsolatok fejlesztése a sport eszközével, különös tekintettel az alap- és középiskolai tanulmányok utáni időszakra.

- A családokon belüli kapcsolatok javítása tartalmas családi sportprogramok kínálatának bővítésével.

A népesség gazdasági aktivitásának előmozdítása (egyének versenyképességének növelése)

- Hozzájárulás az adott munkáltató, illetve a magyar gazdaság versenyképességének javulásához, a javuló egészségi állapotnak köszönhetően a munkaerő kiesés arányának csökkenése révén.

- A munkavállalók produktivitásának növekedése a sportolásnak köszönhető jobb fizikai, szellemi és lelki kondíció eredményeként.

- A tanulási-, koncentrációs, munkabíró képesség növelése a fizikai és szellemi energiák összhangjának sport általi megteremtése révén.

Nemzeti értékek, önbecsülés erősítése

- A nemzeti büszkeség, önértékelés javítása a versenysport társadalmilag releváns területein felmutatott nemzetközi eredmények révén.

- A versenysportolók példamutatása a sport által közvetített értékrenden keresztül.

- Az ország jó hírnevének, nemzetközi ismertségének javítása.

- Lokálpatriotizmus erősítése, különösen a települési csapatok sikerei révén.

Esélyegyenlőség megteremtése és javítása

- A szociálisan kedvezőtlen helyzetű társadalmi rétegek sportolási lehetőségekhez való hozzáférésének javítása, ezen keresztül e társadalmi rétegeknek az országos átlagnál rosszabb egészségi állapotának javítása. Kiemelt figyelmet kell fordítani a szociálisan hátrányos helyzetű közösségekre, iskolákra, ahol a sport társadalmi integrációs és gazdasági felzárkóztatási funkciót is betölthet.

- Esélyteremtés szociálisan hátrányos helyzetű, tehetséges fiataloknak a sportban való érvényesülésre, figyelmet fordítva arra, hogy anyagi problémák miatt ne vesszenek el tehetségek.

- A sporthoz való hozzáférésben mutatkozó területi különbségek csökkentése, infrastruktúrafejlesztés és szakemberképzés növelésével.

- Kiemelt figyelem az idősek szemléletváltására, közösségekbe történő bevonására, aktivizálására.

- A fogyatékos személyek elsősorban integrált sportolási lehetőségeinek bővítése, és nagyobb arányú bevonása a sport területein, ezzel is segítve a társadalomba történő integrálásukat [17].

Ezen célok elérésében egy világméretű sportesemény megrendezése megfelelő eszköz lehet [19], megvalósulásuk a rendezvény pozitív hatásaiként értékelhető.

A nemzetközi sportesemények kapcsán a vendéglátó ország/város óriási média lehetőséget kap arra, hogy bemutatkozzon, és pozitív képet, (image) alakítson ki magáról, illetve meglévő image-ét javítsa 
amely ha jól sikerül a lebonyolítás, jelentős turisztikai, vagy éppen befektetői érdeklődést hozhat a későbbiekben [2]. Kevésbé megfogható, de hosszútávon megerősíthető, hogy egy nemzetközi sportrendezvény során komplex viszony alakul ki a rendező ország image-e, az érintettek nemzeti identitása és a lakosság, illetve az önkéntesek hozzáállása között. Egy nemzetközi sportrendezvény számos olyan értéket képvisel, mint önfegyelem, tolerancia, együttműködés, multikulturalizmus, szolidaritás, csapatszellem, csapatjáték, amelyek nem csupán a sport csúcsát jelentő olimpizmus értékei, hanem legalább annyira a nemzeti identitás, büszkeség részei, alapjai [19]. Ennek következménye, hogy a legfontosabb hosszú távú hatások között szerepel a nemzeti büszkeség, a rendező ország image-ének és az önkéntes mozgalom erősödése. Emellett fontos kiemelni, hogy a sport erkölcsi értékek teremtésére késztet (fair-play, csapatszellem, egészségtudat, tolerancia), segít a társadalmi beilleszkedésben [7, 13, 22], valamint ösztönzi a kulturális cseréket. Kulturális funkciója révén jelentős szereppel bír a különböző nemzetek közötti kölcsönös tisztelet és megértés kialakításában, illetve lehetőséget biztosít az egészséges nemzeti öntudat kibontakoztatására. Integrációs szerepével hozzájárulhat a társadalmi kohézió kialakításához, - hiszen életkortól, nemtől, vallási- és politikai hovatartozástól függetlenül minden társadalmi réteg számára elérhető. Gyakran értékelik a sportban rejlő lehetőségeket a rasszizmus és az erőszak elleni küzdelem adekvát eszközeként. Jóllehet, ennek ellenkezőjére is számos példát szolgáltat a gyakorlat, egyre nagyobb rendfenntartási költségeket okozva a sporteseményeket kísérő összetűzések következtében [19].

A politikai hatások is megtalálhatóak, amennyiben a fejlesztések megtervezéséhez, a beruházások megvalósításához politikai konszenzus szükséges. A rendezés során létrejött kapcsolatok a sportdiplomáciai hatások mellett befolyásolhatják az ország kereskedelmi tevékenységét is.

A támogatók (szponzorok) közreműködése erősítheti a vállalati CSR tevékenységet és új kapcsolatok kialakítását. A nonprofit szektor bekapcsolása a szervező munkába erősítheti a társadalmi kohéziót [22]. Ha az önkéntes programban társadalomtudatos kiválasztás történik, és a segítők felkészítése tudásbővüléssel jár, versenyképességük növekszik.

\subsection{A hatások és időtávok}

A hatások keletkezhetnek a rendezvény előtt, a felkészülési szakaszban, a rendezvény alatt, és a rendezvényt követően is, ezt szemlélteti az 1. Ábra néhány az adott időszakban tipikus hatás feltüntetésével. 


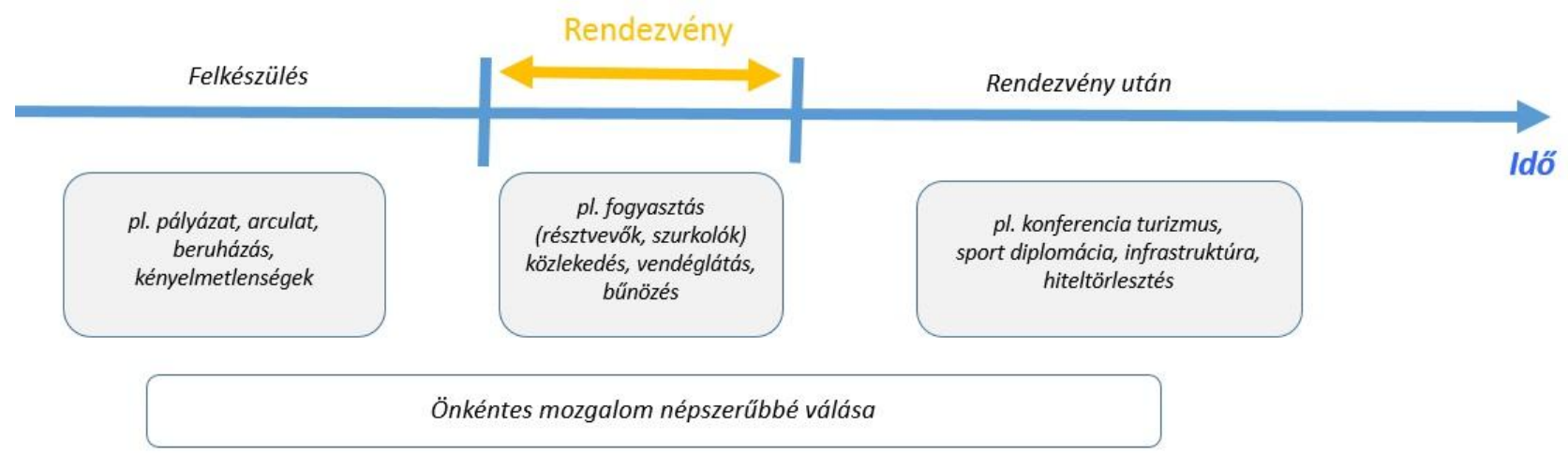

1. ábra: Sportrendezvények hatásai az idő függvényében

(Forrás: saját szerkesztés)

A tervezési, előkészítési időszakban (felkészülés) a legnagyobb hatást a létesítmény- és infrastruktúrafejlesztés jelenti. Ebben az esetben leginkább az építőipar bevételei, beruházásai és az ehhez kapcsolódó munkalehetőségek növekednek meg [2]. A 2017 -es Vizes Világbajnokság esetében ide sorolhatjuk a felsőoktatási intézményekkel megvalósuló projekteket az arculattervezés, a létesítmények látványelemeinek tervezése és kivitelezésének területén, a kapcsolódó szellemi termékek elkészítését, úgy mint megvalósíthatóság, hatásvizsgálatok. Az eseményt megelőző önkéntes kampány, a résztvevők felkészítése, a marketing kampányok nagy része is a rendezvény előtt zajlik. A rendezvény publicitása növelheti a vizes sportágak iránti érdeklődést, ami a fejlesztések, építkezések során létrejött nagyobb kapacitás és színvonalasabb infrastruktúra kihasználásában realizálódik. A sportágak aktív művelőinek létszáma és az utánpótlásbázisa már ekkor is növekedhet [7, 19].

A rendezvények ideje alatt a közvetlen fogyasztás emelkedik meg, amely elsősorban a turizmusból származtatható, hiszen az esemény időtartalma alatt a városokba (országba) nagy számú sportoló, résztvevő és szurkoló érkezik. A közvetlen fogyasztás helyileg az adott városban és térségében továbbá nemzetközi szinten is növekedhet. Helyi szinten a közlekedésből, szálláshelyek kiadásából, vendéglátásból és a különböző a rendezvényhez kapcsolódó szolgáltatásból (biztonsági szolgálat, merchandise tárgyak értékesítése, reklámszolgáltatás értékesítése) állhat össze [2].

Hosszú távon a rendezvényhez kapcsolódó fenntartható munkahelyek, a jól használható létesítmények, az infrastruktúra beruházások jelentik a konkrétan megfogható gazdasági hatásokat (rendezvény után). A rendezvény egyik célja, hogy visszatérő vagy potenciális, új turistákat csábítson a városba $[2,19]$. Továbbá megjelennek azok a nem gazdasági jellegű hatások, amelyek közvetett módon hatást gyakorolnak a rendező ország / város gazdaságára, az érintett sportágak népszerűségére, a lakosság egészségére, életminőségére. Az olimpiák gazdasági örökségében a pozitív hatások érvényesülésének időszakát tíz évre becsülik [11,19]. Kitolható ez az időszak, ha speciális turisztikai vonzerőt jelentő beruházások valósulnak meg [11]. A Vizes VB-hez kapcsolódó uszoda építés és felújítások, további infrastruktúra fejlesztések szorosan kapcsolódnak a Világörökségi helyszínekhez [31]. Összhanban vannak a Duna tengelyben megvalósuló rekreációs övezet kialakításával, esélyt teremtve a speciális komplex turisztikai attrakció felépítésére [19, 21]. 
Az önkéntesek toborzása a Világbajnokság szervező bizottsága önálló Önkéntes Programirodát hozott létre [26, 27], amely számtalan toborzási eszközt megragad. Az önkéntesek kiválasztása során a társadalom széles rétegeit megszólítják, figyelnek a kor szerint megoszlásra, a fogyatékossággal élők bevonására. A felsőoktatási intézményekben célzott kampányt folytatnak. Az önkéntesek felkészítő programja a szükséges szervezési információkon túl érinti a fogyatékos emberekkel való kommunikáció és segítés helyes módját, és annak a felelősségét, hogy munkájukkal az egész országot képviselik. A FINA VB és Masters VB ideje alatt végzett tevékenység közösségi szolgálatként és gyakorlati feladat teljesítéseként is elszámolható. A rendezvény zárásaként minden részt vevő a munkájáról szóló referenciaként is átadható igazolást kap. Az önkéntességgel kapcsolatba hozható hatások minden időszakon átívelnek, ezek:

- Az önkéntesség népszerúbbé válása

- Társadalomtudatos kiválasztás, hátrányos helyzetű személyek bevonása; kiszolgálása

- Az önkéntesek tudásbővülése, tapasztalatszerzése

- Az önkéntesek versenyképességének növekedése.

\section{2017 FINA Vizes Világbajnokság és Masters Világbajnokság Magyarországon}

\subsection{A Rendezvény}

A FINA ("Fédération Internationale de Natation", Nemzetközi Úszószövetség) 2017-es Vizes Világbajnokságot Budapesten és Balatonfüreden rendezik július 14. és 30. között. Budapesten a világ legjobb úszói, vízilabdázói, múugrói, szinkronúszói és óriástoronyugrói, míg Balatonfüreden a legjobb nyílt vízi úszók harcolnak a világelsőségért. Augusztus 7-20. között zajlik a FINA Masters Világbajnokság [18, 26, 27]. Az események szervezése párhuzamosan zajlik, továbbá a két rendezvény egy helyszínen, a sportági versenyek ugyanazon létesítményekben, időben egymást szorosan követve valósulnak meg, jelen tanulmány egy nagy Rendezvényként tárgyalja őket.

A versenyszámok, helyszínek A FINA VB helyszíneként szolgáló fővárosi városrészek és a tóparti Balatonfüred komoly múlttal és kulturális értékkel bírnak:

- A vízilabda mérkőzéseknek helyszínt biztosító Hajós Alfréd Nemzeti Sportuszoda a Margit sziget meghatározó létesítménye, ezért az itt rendezett versenyekre látogatók nem csak egy sportrendezvény helyszínére, hanem egy növényritkaságokkal és védett állatfajoknak otthont adó szabadidő centrumba érkeznek.

- A szinkronúszó versenyek helyszíne a Városliget, a Hősök tere szomszédságában. A műjégpálya épületével szemben található a Vajdahunyad vára, amely a Mezőgazdasági Múzeumnak ad otthont. A Városliget másik meghatározó műemléke a Széchenyi gyógyfürdő, itt található a Fővárosi Állatés Növénykert is.

- Az óriás toronyugrás helyszíne a Batthyány tér dunai partszakasza. A versenyek hátterében a Duna part meghatározó épületegyüttesét a Parlamentet látják majd a helyszínen és a sportközvetítések nézői a képernyőkön keresztül. 
- Az úszó számok és a toronyugrás helyszíne a Duna partján a Duna Aréna (építési szakaszban Dagály Úszókomplexum) Budapest Vizafogó városrészében épült. Az építkezés egy teljes városrészfejlesztési program része. Az épület több mint versenyuszoda, a fejlesztéssel a Dagály területén az ország legkiemelkedőbb sport- és fürdőközpontja jön létre, amely méltó helyszíne lesz nemzetközi sporteseményeknek.

- A nyílt vízi úszószámok megrendezésének helyszíne a Balaton legrégebbi fürdővárosa Balatonfüred.

A vizes Világbajnokságokon résztvevő nemzetek és sportolók száma évről évre bővül, és a versenyszámok köre is egyre szélesebb. Tekintve a tendenciát a 2017-es Vizes VB résztvevői és nézettségi adatait a 2015-ös Kazany-i adatokat alapul véve becsülhetjük. Ezek szerint Budapesten és Balatonfüreden több, mint 190 nemzet, több, mint 2600 versenyzője vesz részt a versenyeken [30].

A Rendezvény hatásainak mértéke és az időbeli kiterjedés alapvető meghatározója a publicitás[11]. A nézettségi adatok becslésére alkalmas lehet a kazanyi 16. FINA Világbajnokság össznézettsége, ahol a két évvel azelőtti, 4.53 milliárdos adatot messze felülmúlva 6.84 milliárdra ugrott a tévés nézőszám. Ez a szám a 16 nap valamennyi, a világbajnokságról bármilyen formában beszámoló televíziós program nézettségének összesítése. A világ különböző tévé társaságai 5728 órányi közvetítést adtak a 16. FIMA Világbajnokságról - csaknem 600 órával többet, mint 2013-ban [30]. Mindez mutatja az vizes sportok emelkedő népszerűségét, amely már a londoni olimpia alkalmával is kézzelfogható volt: 2012-ben valamennyi sportág közül az úszóviadalokat követték legtöbben a játékok során a képernyők előtt. Ennek következményeként a FINA-hoz tartozó diszciplinákat a NOB a sportági rangsorolásában "A" kategóriába emelték [8, 30]. Ez egyszersmind azt is előrejelzi, milyen széles közönséghez jutnak majd el a Világbajnokságról sugárzott képek 2017 nyarán, így Magyarország semmihez sem fogható, globális promóciós lehetőséghez jut [30]. 2016 december 26-án értékelték a hivatalos honlapon [26] a jegyeladásokat annak apropóján, hogy pontosan 200 nap volt a kezdésig. Az első három hétben több mint 30000 jegyet értékesített a partner vállalkozás, ami felülmúlta az erre az időszakra megcélzottt elvárást (ezt elősegítették az első jegyértékesítési szakaszra megállapított kedvező jegyárak).

A Masters (vagy senior) viadalokon csak alsó korhatár van: az úszóknál már 25 évesen át lehet nyergelni az „öregfiúk” közé, ugyanakkor rendszeresen érkeznek 80, sőt, 90 év fölötti résztvevők is, akik 14 különböző korcsoportban mérik össze tudásukat. Masters VB-ből 1986-ban rendezték meg az elsőt, amely mára a résztvevők létszámát tekintve a FINA legnagyobb eseményévé nőtte ki magát. A regisztrált szeniorúszók száma világszerte 60,000 fő - közülük általában 10 ezren elutaznak a világ bármely végébe, amikor a világbajnokság startol És ez csupán az úszók mezőnye, a másik négy sportág tovább duzzasztja ezt a számot - amely általában 12 ezer környékén áll meg, legalábbis a versenyzők szintjén (2012ben, Riccionéban 12 410-en vettek részt, míg két évvel később, Montrealban több mint 10 ezren, immár 97 ország képviseletében, ami új rekord), de 2017-ben akár 20-22 ezer is lehet a vb-re érkezők létszáma, hiszen a sportolókat rendszeresen elkíséri egy, de inkább több hozzátartozó. A Masters VB mára már egy hatalmas dzsemborivá nőtte ki magát, amely a sportolók helytállásán, illetve a sportolás, a mozgás generációkon átívelő promócióján túl elsősorban turisztikai esemény. A Masters-résztvevők számára legalább annyira fontos a mindenkori helyszín megismerése, mint maga a versengés. A szervezők a verseny feltételek biztosítása mellett gazdag városnéző programkínálatról is gondoskodnak [27]. 


\subsection{Magyar specialitások, befolyásoló tényezők}

Egy Magyarország megyéire is településtípusonként reprezentatív 1200 fős 2015-ben lezajlott kutatásban vizsgálták a magyar háztartások sportfogyasztási szokásait. [6] A 2015-ös vizsgálat kérdőívének egyik fontos célja volt felmérni, hogy a válaszadók mely sportágakat preferálják, melyekben aktívak, akár többet is megjelölve, azaz milyen az egyes sportágak népszerűsége. A sportágak népszerűségi listáját azon válaszadók eredményei alapján állították össze, akik egy korábbi kérdésnél jelezték, hogy sportolnak. A legnépszerűbbnek a kerékpározás bizonyult, míg a második legnépszerübb az úszás. A 2015-ös hazai háztartások sportfogyasztását vizsgáló kutatás eredményei a sportszolgáltatások fogyasztásával összefüggésben azon megállapításokat is alátámasztották, melyek szerint több sportszolgáltatás esetében - mint sport célú utazás, sportcsatorna előfizetése, sporttal kapcsolatos tartalmak vásárlása, táplálék-kiegészítők vásárlása - egyértelmű kapcsolat található a sportbeli aktivitással [10]. Az említett szolgáltatások esetében az aktív sporttevékenységet a napirendjükbe iktató válaszadók nagyobb arányban számoltak be igénybevételről, mint a sportban inaktívak. Azaz elmondhatjuk, hogy az egyébként is aktívan sportolók passzív sportfogyasztóként is intenzívebben vannak jelen a sportpiacon és a sporttal szembeni pozitív attitúdjeik ezen a területen is jelentkeznek [6].

A sportsikerek csúcsát Magyarországon az olimpiai érmek képviselik [1]. Az újkori olimpiák történetének első két magyar aranyérme Hajós Alfréd nevéhez fűződik 100 és 1200 méteres gyorsúszásban. [23]. A sportágak rangsorát a magyar olimpiai éremtáblázatban (1896-2016) az úszás 2. helyen 73 éremmel, míg a vízilabda 9. helyen 15 éremmel szerepel[8, 23]. A 2015-ös úszóvilágbajnokságot („úszó, műúszó, műugró és hosszútávúszó-világbajnokság”) Kazánban (Kazany), Oroszországban. Ugyanitt, és ugyanekkor rendezték a férfi- és női vízilabda-világbajnokságot is. Magyarország a világbajnokságon 52 sportolóval képviseltette magát, akik összesen 3 arany-, 3 ezüstés 4 bronzérmet szereztek. A 2013-as vizes VB-t Barcelonában, Spanyolországban rendezték. Magyarország a világbajnokságon 47 sportolóval képviseltette magát. akik 4 arany-, 1 ezüst-, és két bronzérmet szereztek. Magyarország a legsikeresebb vízilabda nemzet a Világbajnokságok on szerzett érmek tekintetében [26].

Az élsportot hazánkban elsősorban az olimpikonokkal azonosítják, akik nemzeti példaképpé válnak, de az alacsonyabb szinteken versenyzők is a lokális presztízs képviselői [7]. Elsősorban a csapatsportokban, és az olimpiai egyéni számokban is a kiemelkedő játékosok, sztárok jövedelmük nagyobb hányadát nem a munkaadó egyesülettől, hanem egyéni szponzoráció révén szedik be. Az egyéni szponzorációban látható jelentősebb eltérések magyarázataként a sikereken túl az egyén személyiség jegyeit, ez esetben közvélemény formáló képességét (opinion leader szerepkör) találjuk. A hivatásos sportban elért sikerek olyan externális javak, amelyek a nemzeti és lokális identitástudatra, az ún. életminőség faktorra hatnak, az ország és fokozottabban a lokális imázs és a társadalmi kapcsolatok erősödésében jelentkeznek. Hsonló externális hatásként beszélhetünk az utánpótlás számára megjelenített sportolói példakép állításáról, amely az egyes sportágak kipróbálására, majd űzésére ösztönzi a fiatalságot. Erre pedig a látványsportágak professzionális sportolói képesek a leghatékonyabban, hiszen a médián keresztül ők juttathatják el leggyakrabban a sportra hívó 
üzeneteiket a fiatalság számára [1]. Hosszú Katinka a riói olimpián 2016-ban 3 arany (egyik világcsúccsal, másik olimpiai rekorddal) és 1 ezüstéremmel az olimpia legeredményesebb úszója volt egyéni számokban. A kanadai Winsdorban rendezett rövid pályás világbajnokságon hét arany- és két ezüstérmet szerzett, és a rövid pályás világbajnokságok legeredményesebb női úszójává vált. 2017. január 12-én sorozatban negyedszer, összességében ötödször választották Magyarországon az év női sportolójának, majd átvehette az év európai sportolójának járó díjat is a Nemzetközi Sportújságírószövetség (AIPS) képviselőjétől is. Magyar sportoló ennek előtte legutóbb 1992-ben érdemelte ki ezt a díjat Egerszegi Krisztina (szintén többszörös olimpiai bajnok úszónő) révén [29, 33]. Az úszónő saját brand-et épít, saját márkás termékekkel is jelen van a sportszerek piacán [25].

A vizes sportok az innovatív sportok közé tartoznak, a tudományos eredmények és technikai újítások alkalmazása egyaránt jellemző az uszodákban és az azon kívüli szakmai munkában [5, 9, 14, 24]. Innovatív szemléletet már a tehetségek kiválasztásánál is tetten érhetünk. Maga a tehetséggondozás a tervszerű utánpótlásnevelés, a 1900-as évek elején a vízilabdában Komjádi Béla nevéhez füződött. Őt tartják az új technikát követő levegőjáték megteremtőjének is [5, 24]. A vizes sportok területén a sportruházat gyártók, és a sport szakemberek egyaránt innovatív megoldásokkal állnak elő. Az úszó ruházat evolúciója a közönség számára is követhető, azonban a divat befolyása helyett ezen a területen az aerodinamikai kisérletek eredményei alakítják a trendet [9]. A vizes sportágak technikai szempontból azért is kihívást jelentenek, mert a sportolók vízben vagy víz alatt tartózkodnak. Ez bonyolítja a testere helyezett szenzorok elhelyezését, a rádiófrekvencia terjedését, a más felszíni sportoknál használt adatelemzési algoritmusok alkalmazását. Kevésbé használható a versenyzők verbális instruálása. Ezen nehézségek küszöbölése azonban lehetőséget teremt a folyamatos innovációra. A videotechnológia, a biometrikus adtok gyűjtése és kiértékelése jelentik ma az úszósport egyik tudományos terepét [14]. A tervezett életmód a speciális étkezési szokások, diéták is szerves részei az edzésmódszereknek [25]. Az újítások hátterében a tudományos eredményeket találjuk.

A vizes sportokhoz köthető számos történés messze túlmutat egy-egy sportversenyen, sportolói pályafutáson. 1956-ban a Melbourn-i Olimpia győztes Magyar vízilabdacsapatának elődöntőben lezajlott küzdelmét a Szovjet válogatottal szemben a világsajtó nem csupán sporttörténeti szempontból értékelte. A mérkőzés és a körülmények, az akkori magyar társadalmi helyzet, egy mozifilmben is feldolgozásra kerültek. Szintén túlmutatott egy vezetőváltáson az Úszószövetség széles sajtó és közérdeklődés mellett lezajlott 2017 januári elnökválasztása [28, 33].

1972. november 16-án született meg a Világ Kulturális és Természeti Örökségének Védelméről szóló UNESCO egyezmény, amelyet eddig 189 tagország ratifikált. Az Egyezményhez Magyarország 1985ben csatlakozott, jelenleg nyolc világörökségi helyszínnel képviselteti magát a rangos Világörökségi Listán [31]. Budapest Duna-parti látképe, a Budai Várnegyed, az Andrássy út és történelmi környezete a nyitó ünnepségtől minden versenyhelyszínen át a záró ünnepségig szerepet kapnak. Ezen helyszíneket is érintő komplex turisztikai attrakció jöhet létre.

A 2024 - es Olimpia megrendezésére benyújtott magyar pályázat visszavonásáig 2017 február közepéig [20] szinergiában zajlottak a 2024-es olimpia megrendezésének jogáért folytatott és a 2017 Vizes VB előkészületei, a kommunikációs kampányok, a társadalmi egyeztetés. 2016 szeptembertől iker látogatóközpont mutatta be a projekteket. A két, egyenként 200 négyzetméteres 
látogatóközpontot a Dunán, egy közel 700 négyzetméteres uszályon építették fel a Batthyány téri kikötőnél [34]. A Vizes Világbajnokság szempontjából a közös kommunikációs kampány szélesebb ismertséget hozhatott, ugyanakkor ezzel a visszalépéssel "mellékszereplőbő egyeduralkodóvá" vált a VB az ilyen nagyságrendű magyar rendezésű sportesemények között az elkövetkező évekre is.

\subsection{Társadalmi hatások a felkészülési időszakban}

A 2015. XXXIII. törvény bevezető szakaszának értelmében a törvényalkotó célja a Rendezvény megrendezésének támogatásával a gazdaság és a turizmus élénkítése, a sport- és szabadidős szolgáltatások színvonalának emelése, valamint a hosszú távú város rehabilitáció megvalósítása [18].

A versenysport kiemelkedő szerepet játszik az országimázs építésben, a hazai adatok szerint a versenysport a negyedik legfontosabb tényező az ország sikeressége szempontjából [19]. Az újabb és újabb sikeresen megrendezett sportversenyek tovább fokozzák az érdeklődést a nemzetközi szövetségekben. A 2017 FINA VB sikeres megrendezése komoly tényezőként szerepelhetett volna a 2024-es Olimpiai Pályázatban.

A felkészülési időszakban pozitív hatásként jelentkezik a beruházások, a szervezés munkahelyteremtése $[11,19]$. Negatív hatásként értékelhető az építkezésekkel járó kellemetlenségek sora, mint a forgalmi rend megváltozása szárazföldön és a Dunán, a zajterhelés és a szállópor koncentráció növekedése, a zsúfoltság, a korrupció növekedésének esélye. A létesítmények átadását követően a pozitív hatások kerülnek előtérbe a Rendezvény kezdetéig. A Rendezvényhez kapcsolódó infrastruktúra fejlesztések hozzájárulnak a környéken élők, és az oda rekreációs céllal érkezők életminőségének javulásához. A Duna Aréna (építési szakaszban: Dagály Úszókomplexum) felépítése, a Hajós Alfréd Nemzeti Sportuszoda, a balatonfüzfói uszoda felújítása, a vizes sportok művelőinek szélesíti a lehetőségeit [26]. A Dagály sétány megépítése, a Népfürdő utca és a Vizafogó utca felújítása, a Gyalogos híd a Rákos - patakon, és a Margit szigetre, az Alsó rakpart megépítése [21] a közlekedési infrastruktúra jayíitásával a szabadidős sporttevékenységet űzők lehetőségeit is növelik elsősorban a gyaloglás, futás, kerékpározás terén. A 2. Ábra hatástérképe szemlélteti, hogy hogyan gyűrűzhet tovább az infrastruktúra és létesítményfejlesztés hatása. 


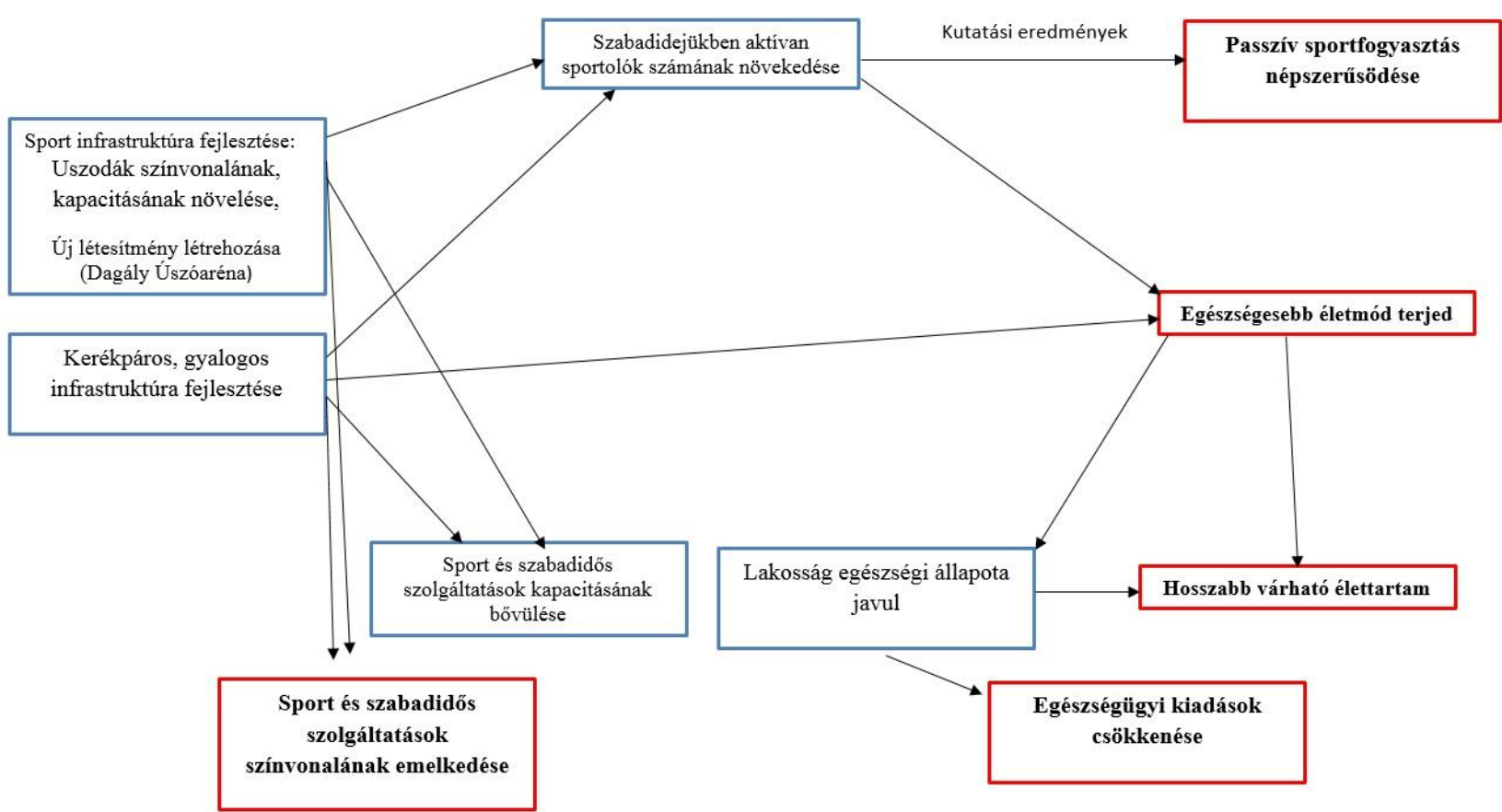

2. ábra: Hatástérkép beruházás, infrastruktúra

(Forrás: saját szerkesztés)

A Duna által kettészelt, a hegyes-völgyes és a síkvidéki oldalra osztott és a folyón átívelő karcsú hidak sorával összekötött Budapest egyedi panorámát nyújt. Budapest - a Duna-partok, a Budai Várnegyed és az Andrássy út - világörökségi helyszínek kulturális kategóriában [26, 27, 31]. Megjelennek a kommunikációs kampányban már a felkészülési időszakban is, felkeltve az érdeklődést a Rendezvény, a város és az ország iránt, ami gazdasági hatásban (jegyeladás, turizmus) realizálódhat. A vizes sportokhoz köthető fejlesztések erősíthetik Budapest fürdőváros imázsát. Kockázati tényezőnek ítélhető meg a turisztikai szezonhatás fennmaradása.

A sport, a tudományos élet és a képzési rendszer egyedi kapcsolata jött létre a FINA VB kapcsán. A világbajnokságot megjelenítő logok, plakátok, figurák első változatai sok vitát váltottak ki, ezért a szervezőbizottságnak új tervek után kellett nézni. A Matyó népművészet ihlette végleges arculatot a KREA művészeti iskola harmadéves hallgatója tervezte. [26, 27]. A matyó díszítőelem-együttes 2012 decemberében felkerült az UNESCO szellemi kulturális örökség listájára [31]. A szervezőbizottság felkérésére a MOME (Moholy-Nagy Művészeti Egyetem) hallagtóinak tervei alapján készült el a Dagály Úszóarénában a jakuzzik üvegmozaikja, a vizes sportok olimpikonjait bemutató Hősök Fala és a vizes sportágak interaktív bemutatkozó felülete [32]. A 2017 -es Vizes VB esetében ide sorolhatjuk a felsőoktatási intézményekkel megvalósuló olyan projekteket, mint a kapcsolódó szellemi termékek elkészítését, úgy mint megvalósíthatóság, hatásvizsgálatok. Az eseményt megelőző önkéntes kampány, a résztvevők felkészítése, a marketing kampányok. A tudományos konferencia előadások és publikációk születése is az egyik társadalmi hatás, és mint jelen tanulmány bizonyítja, már a felkészülési időszakban is jelen van. 
Egyrészt a hivatalos támogatók (FINA és nemzeti) [26, 27], a Rendezvény minden színterén és helyszínén megjelennek logójukkal, termékeikkel, szolgáltatásukkal. Másrészt saját kommunikációs csatornáikon keresztül tovább növelhetik a Rendezvény és ezáltal Magyarország ismertségét A támogatók (szponzorok) közremúködése erősítheti a vállalati CSR tevékenységet és új kapcsolatok kialakítását.

A nonprofit szektor bekapcsolása a szervező munkába erősítheti a társadalmi kohéziót.

A rendkívüli beruházások új építési technológiák elsajátítását kívánják meg, ez a vállalkozók és az alkalmazottak számára egyedi tudásbővülést jelent. Kockázati tényezőnek bizonyulhat az idegen nyelvtudással kapcsolatos hiányosság, amely sok közremúködő (a technikustól a biztonsági őrökön át a takarítókig) esetében előfordulhat.

A kiemelt sportágfejlesztési programban érintett vizes sportokhoz kötődő infrastrukturális fejlesztések javuló körülményeket biztosítanak az élsportolóknak a felkészüléshez, ez tovább fokozhatja a sikereket.

A kutatási eredmények azt támasztják alá, hogy a megváltozott munkaképességű, fogyatékossággal élő emberek társadalmi befogadásának kiváló eszköze a sport [7, 13]. A FINA VB kiváló alkalmat teremthet arra, hogy ráirányítsa a figyelmet az érintett csoportokra. A rendezvény kapcsán különös tekintettel kell lenni az akadálymentes közlekedés biztosítására, kiemelten kezelve az ideiglenes létesítményeket. Ha az önkéntesek képzési programjában szerepelnek a fogyatékossággal élők segítésének módszerei, a szükséges kommunikáció és viselkedés elsajátítása, és az Önkéntes Programiroda [26] a kiválasztás során is törekszik arra, hogy soraiban tudhasson olyan személyeket, akik maguk is valamilyen hátránnyal küzdenek, akkor már a felkészülési időszakban is megvalósulhat a társadalmi felelősségvállalás ezen a területen. Az önkéntesek nagy száma miatt a feléjük közvetített fogyatékossággal összefüggő ismeret társadalmi tudásbővülést jelenthet.

A biztonsági kockázat növekedése kevéssé jellemzi a felkészülési időszakot. A helíszínbejárások, az elkészült létesítmények hivatalos átadási rendezvényei idején lehet számolni a terrorveszély lehetőségével, ami fokozott rendőri jelenlétet, forgalmi és parkolási korlátozásokat eredményezhet, amely a lakosság egy része számára csak kevésbé tolerálható. A felkészülés és a rendezvény biztonsági szolgáltatásokat érintő szakasza hozzájárulhat a nagy létszámú nemzetközi események kapcsán hasznosítható tudásbővüléshez. Az infrastrukturális beruházások komplex városrész rehabilitációt is jelentenek, amelyek lényegesen jobb közlekedési körülményeket eredményeznek. Szélesebb utcák és járdák, jobb közvilágítás jellemzi majd azokat a városrészeket, ahol a versenyek zajlanak, ezeken a területeken a verseny után is megmarad a jobb közbiztonság.

A negatív hatások erőteljesen megjelennek a felkészülési időszakban. Az építkezések kellemetlenségekkel járnak. Megváltozik a forgalmi rend az érintett városrészekben, nő a zajterhelés, fokozódik a szállópor koncentráció. Átmeneti zavarokkal lehet számolni a közüzemi szolgáltatásokban. Megjelenhet a korrupció [11]. A fejlesztések kockázata, hogy más fejlesztésektől vonhatják el a forrásokat, illetve, hogy növelhetik a regionális különbségeket. 


\section{Empirikus kutatás a Debreceni Egyetemen, a Rendezvény előtt hat hónappal}

\subsection{Jövő managerei a Debreceni Egyetemen}

$\mathrm{Az}$ ország legnagyobb hallgatói létszámmal bíró egyeteme a Debreceni Egyetem, számos tudományterülete mellett, néhány évvel ezelőtt, felismerve a sporttudományban rejlő számtalan lehetőséget, megteremtette annak alapjait, hogy magas szintű oktatási, kutatási, fejlesztési, innovációs és szolgáltatási egység jöjjön létre. A Gazdaságtudományi Karon a Sportgazdasági és -Menedzsment tanszék 2009-ben alakult, majd 2015-ben a Sporttudományi Koordinációs Intézet, melynek az oktatás és tudományos tevékenység koordinálása mellett egyfajta regionális sporttudás-központként, küldetése, hogy minden a sporttal, fizikai aktivitással, testneveléssel kapcsolatos területen segítse és támogassa a régiót [35].

A Rendezvény lebonyolítását jelentős számú önkéntes segíti (mintegy 3500 fő). A nyári időszakban az egyetemistáknak van annyi szabadideje, hogy a VB önkénteseitől elvárt óraszámban a szerevezők rendelkezésére álljanak [26, 27]. Jó eséllyel ők azok is, akik a megfelelő nyelvtudás birtokában vannak. Közülük a sportszervezők, a sportmenedzserek az elméleti tudás birtokában szerezhetnek gyakorlatot a felkészülés során a rendezvényszervezés területén, részesévé válhatnak egy világeseménynek.

A magyar sportfogyasztást vizsgáló tanulmányok tanúságai szerint az egyetemisták egy bővülő szegmenst képviselnek az aktív és a passzív sportfogyasztás területén egyaránt [6, 10, 22].

Az egyetemi hallgatók véleményének feltárása azért is fontos lehet, mert ők lesznek a jövő vélemény formálói, magas pozíciók várományosaiként pedig a jövő döntéshozói [4,12] akár kormányzati, akár civil, akár a verseny szférában.

Az empirikus kutatásunk célja az volt, hogy megvizsgáljuk, jelen vannak-e, - és ha igen, akkor milyen mértékben, a megkérdezettek körében azok a befolyásoló tényezők, amelyek a korábbi fejezetekben bemutatott társadalmi hatásokat felerősíthetik. Ter mészetesen arra is kíváncsiak voltunk, milyen a VB ismertsége a kezdés előtt 6 hónappal, és mennyire büszkék arra a megkérdezett egyetemi hallgatók, hogy Magyarország rendezi a 2017-es Vizes Világbajnokságot.

\subsection{Adatfelvétel, minta}

Az adatfelvétel a Debreceni Egyetem karain meghirdetett nem szakmai tantárgycsoport vizsgatevékenységéhez kapcsolódott és 2016 december 19. és 30. közötti véletlenszerűen kijelölt vizsganapokon történt. 


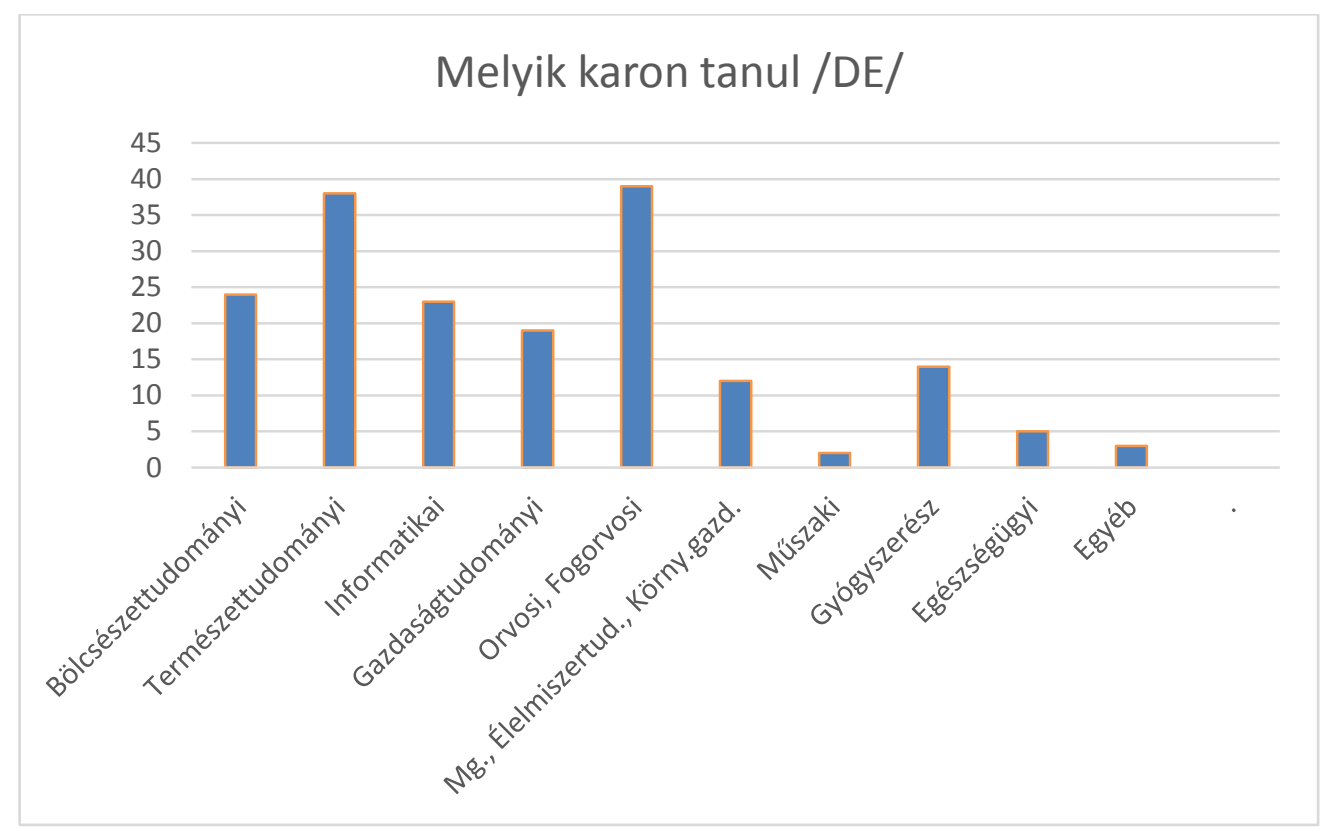

3. ábra: A válaszadók megoszlása karonként (DE)

(Forrás: saját szerkesztés)

\subsection{Módszerek}

A hatáselemzés dokumentumok és media megjelenések tartalomelemzésével történt.

Az egyetemi hallgatók véleményének feltárására sajját szerkesztésű kérdőívet használtunk. 181 fő elsődleges adatfelvétele után újabb 60 kérdőívet töltöttek ki a vizsgálati személyek. Ebből a második adatfelvételi egységből további 33 kérdőívet értékeltünk ki. A kiválasztás szempontja az volt ( a pótlólagos adatfelvétel kérdőíveiből), hogy minél jobban közelítsünk az egyetemi karok szerinti reprezentativitáshoz $(\mathrm{N}=214)$.

Az adatok elemzéséhez az IBM SPSS Statistics 19 szoftvert használtuk.

\subsection{Eredmények}

A Rendezvény nyitóünnepsége előtt 6 hónappal a válaszadók 77,6\%-a tudott róla, hogy Magyarországon 2017-ben Vizes Világbajnokságot rendeznek.

Kíváncsiak voltunk rá, hogy mennyire éreznek büszkeséget a hallgatók tekintet nélkül arra, hogy tudtak az eseményről, vagy nem, hogy egy ilyen nagyszabású sportrendezvényt rendez az ország. Rövid tájékoztatást kaptak a Reendezvényről néhány sorban. A kérdőívben a kérdésre:

\section{„Ön mennyire büszke rá, hogy egy ilyen sportesemény lesz Magyarországon?”}

10 fokozatú skála egyetlen értékének megjelölésével lehetett választ adni (kombinált szemantikus differenciál és Stapel skála): Szégyenlem -5 -4 -3 -2 -1 012345 Hatalmas büszkeséggel tölt el.

A kérdésre adott válaszok leíró statisztikáját mutatja az 1. Táblázat 
A Vizes VB megrendezésével kapcsolatban érzett büszkeség

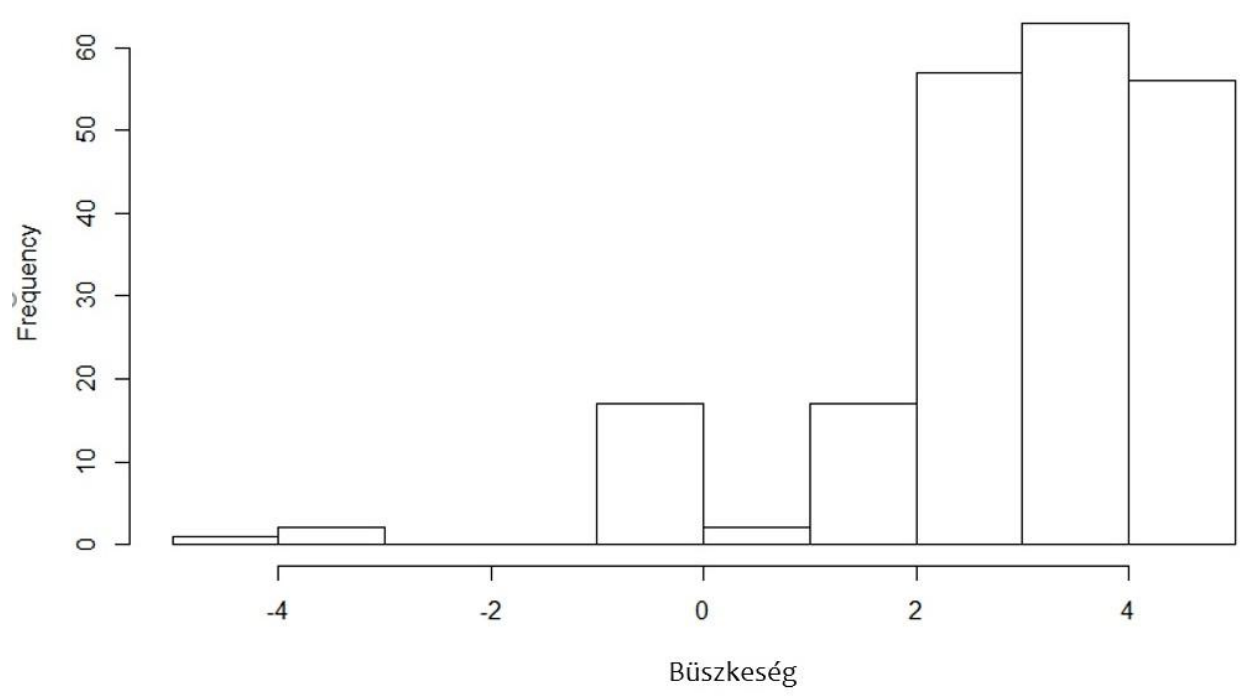

4. ábra: A Vizes VB megrendezésével kapcsolatban érzett büszkeség hisztogramja $(N=, 214,4$; mean:3,4; std. dev.:1,618)

(Forrás: saját szerkesztés)

A megkérdezettek inkább büszkék arra, hogy Magyarországon rendezik a Vizes VB-t, mint szégyenlik. Sőt, ami azt illeti a büszkeségük átlaga közelebb van a nagyon büszke végponthoz ( mean:3,4; median:4, a maximum:5). A kiugró értékeket $(-4,-4,-5)$ tüzetesebben megvizsgálva (más változók addícionális elemzése) kijelenthetjük, hogy ezen adatok az egyetemistáknak egy valós, szűk szegmensét képviselik.

A lehetséges befolyásoló tényezők közül vizsgáltuk a vizes sportok népszerűségét, és a „sztárok” ismertségét.

A kérdőívben két kérdésben jelent meg a sportpreferencia. Ezek:

\section{„Melyek a kedvenc sportágai mint szurkoló/néző?”}

\section{„Melyek a kedvenc sportágai mint aktív múvelője a sportágnak?”}

Mindkét nyílt kérdésnél három sportágat nevezhetett meg a kitöltő.

\begin{tabular}{|l|c|c|}
\hline & Aktív/művelő & Passzív/néző \\
\hline 1. & labdarúgás & labdarúgás \\
\hline 2. & úszás (21\%) & úszás $(39,72 \%)$ \\
\hline 3. & futás & kézilabda \\
\hline
\end{tabular}

1. táblázat: Sportági preferenciák a mintában

(Forrás: saját szerkesztés) 
Az eredményeket az 1. Táblázat mutatja. Az úszás a passzív sportfogyasztás tekintetében a második legnépszerűbb sportágnak bizonyult. Ennek hátterében a hazai vizes sportok sikerei állhatnak, amit az is alátámaszt, hogy a sikeres vizes sportolók ismertsége magas (2. Táblázat). Az aktív sportfogyasztás sportági rangsorában is az előkelő második helyezést érte el az úszás, a kiemelkedően magas infrastruktúra igénye ellenére.

A válaszadók két nyílt kérdésben nevezhették meg a vizes sportólókat, köztük Hosszú Katinkát. Ezek a következők:

„Kérjük soroljon fel magyar sportolókat vizes sportágakban! Maximum 3-at soroljon fel!” „Kérjük soroljon fel egykori és/vagy jelenlegi magyar olimpikonokat! Maximum 5-öt soroljon fel”

\begin{tabular}{|l|c|c|}
\hline & Sportoló & Sportág \\
\hline 1. & Hosszú Katinka & úszás \\
\hline 2. & Gyurta Dániel & úszás \\
\hline 3. & Cseh László & úszás \\
\hline 4. & Egerszegi Krisztina & úszás \\
\hline 5. & Kásás Tamás & vízilabda \\
\hline 6. & Kapás Boglárka & úszás \\
\hline
\end{tabular}

(Forrás: saját szerkesztés)

A 2. Táblázat a nyílt kérdésekre adott válaszok alapján összeállított sportolói rangsort mutatja. A vizes sportolók egyeduralmát az első 6 helyen árnyalja, hogy a kérdőív részben és a vizes sportolókra vonatkozó sportági kérdés egészében vizes sportolók megnevezését indukálja. $\mathrm{Az}$ adatok rendezésekor kialakításra került egy olyan változó, amelyben az került kódolásra, hogy megnevezte-e Hosszú Katinkát a kitöltő a sportpreferencia kérdések valamelyikében. 

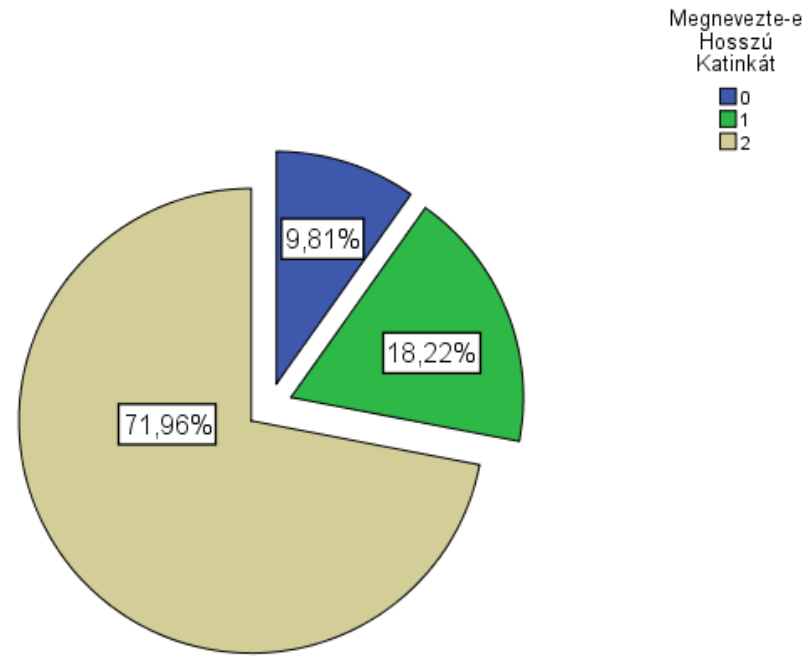

5. ábra: Hosszú Katinka ismertsége a megkérdezettek körében (0: nem nevezte meg; 1: vizes sportolóként vagy olimpikonként megnevezte; 2: vizes sportolóként és olimpikonként is megnevezte)

(Forrás: saját szerkesztés)

Hosszú Katinka ismertsége 90\% fölötti. A megkérdezettek közel 72 \%-a mindkét nyílt kérdésben, a vizes sportolóknál és az olimpikonoknál is megnevezte az úszónőt.

A kereszttábás elemzések során nem sikerült szignifikáns összefüggést feltárni a megkérdezettek neme, a vizes sportági preferenciák, és Hosszú Katinka megnevezése változók között.

\section{3. Összefoglalás}

Egy világméretű sportesemény sikeres megrendezése amellett, hogy növeli a nemzeti büszkeséget, a különböző társadalmi csoportokra és az egyénekre is komplex hatást gyakorolhat. A kutatások alátámasztják, hogy egy sportesemény alkalmas lehet arra, hogy a passzív sportfogyasztókat (a nézőket, szurkolókat) arra ösztönözze, hogy aktívan is sportoljanak. Hasonló hatása lehet az adott sportágban elért hazai sportsikereknek (vízilabda, olimpiai bajnok úszók). Szintén kiemelt szerepe lehet az adott sportesemény sikerében, hírértékében és az adott sportág népszerűségének növelésében a „sztárok”, a sportág legnépszerűbb képviselőinek szereplése(Hosszú Katinka).

A Magyarországon megrendezésre kerülő 2017 Fina Vizes Világbajnokság a világ egyik legnagyobb sporteseménye. A vizsgálat során feltártunk a Rendezvény hatásainak erősségét befolyásoló tényezőket. A felkészülési időszakban ezek közül jelentősnek ítéltük meg a vizes sportágak hazai nagy népszerűségét, a vizes sportágakban elért magyar sikereket, és a "sztárok" ismertségét az érintett sportágakban, ami szoros összefüggésben van a sportsikerekkel. Magyarországon a vizes sportok népszerűsége töretlen, az úszás, a magas infrastruktúra igénye mellett is a második legnépszerűbb sportág. A vizes VB-k abszolút éremtáblázatát a vízilabdában Magyarország vezeti. Hosszú Katinka 
jelenleg a világ legeredményesebb úszónője, a 2016-os Rió-i Olimpián a legsikeresebb magyar sportoló, a második legsikeresebb nyári olimpikon nő a világon. A vizes sportok jelentőségét tovább árnyalahatja, hogy szorosan kapcsolódnak tudományos és technikai innovációkhoz, társadalmi katalizátorként hatással lehetnek a sport hagyományos értékeinek közvetítésére, segíthetik a megújulást.

Feltártuk azon társadalmi hatásokat, amelyek már a Rendezvény kezdete előtt jelentkezhetnek.

A Rendezvény több, mint 3000 önkéntesét elsősorban az egyetemista korosztályból toborozzák. Így érintettségük okán valamint azért, mert ők lesznek a jövő vélemény formálói, magas pozíciók várományosaiként pedig a jövő döntéshozói akár kormányzati, akár a verseny szférában fontos lehet véleményük feltárása. Arról nem is beszélve, hogy már jelenleg is ők a média egyik legnagyobb célcsoportja, mely státuszban még néhány évtizedet eltölthetnek.

A Debreceni Egyetemen, ami az ország legnagyobb hallgatói létszámmal bíró felsőoktatási intézménye, végzett kérdőíves kutatás (N=214) eredményeit értékelve azt találtuk, hogy a megkérdezettek büszkék arra, hogy Magyarországon rendezik a 2017 Vizes Világbajnokságot és Masters Világbajnokságot. Hosszú Katinka ismertsége rendkívül magas (90\%). A vizes sportok preferenciája a kitöltők közel felét jellemzi (45,25\%). Az úszás bizonyult a második legnépszerűbb sportágnak ebben a mintában az aktív és a passzív sportfogyasztás tekintetében egyaránt. Ezen eredmények igazolni látszanak a leírt befolyásoló tényezők szerepét a Rendezvény felkészülési időszakának társadalmi hatásaiban a rendezés ismertségén $(77,6 \%)$ és az ezzel kapcsolatban érzett büszkeségen (mean: 3,4; min.:-5; max.:5) keresztül.

\section{Hivatkozások}

[1] P. Ács, (2015), Sport és Gazdaság, Pécsi Tudományegyetem Egészségtudományi Kar

[2] K. András, T. Máté, (2016) Nemzetközi sportrendezvények turisztikai hatásai, in Rajnai Z., Fregán B., Marosné Kuna Zs. (szerk.): Tanulmánykötet a 7. BBK előadásaiból, Óbudai Egyetem

[3] K. András, T. Máté, (2016), Hazai rendezésú megasport események gazdasági hatása, Start, I/1 pp.13.-24.

[4] N. Deutsch, L. Berényi, (2016), Personal approach to sustainability of future decision makers: a Hungarian case, Environment development and sustainability, First Online: 08 November 2016

[5] M. Hraste, M. Bebić, M, R. Rudić, (2013), Where is today's Water Polo Heading? An Analysis of the Stages of Development of the Game of Water Polo. NAŠE MORE : znanstveno-stručni časopis za more i pomorstvo, 60(1-2), S17-22. Preuzeto s http://hrcak.srce.hr/104451A.

[6] A. Kovács, D. Paár, G. Elbert, Zs. Welker, M. Stocker, P. Ács, (2015), A magyar háztartások sportfogyasztási szokásainak felmérése, Pécsi Tudományegyetem Egészségtudományi Kar 
[7] T. Laczkó, E. Rétsági, (2015), A sport társadalmi aspektusai Pécsi Tudományegyetem, Egészségtudományi Kar

[8] T. Madarász, (2016), Néhány választott egyéni sportág jelenlegi helyzetének és versenyképességének elemzése Magyarországon, International Journal of Engineering and management sciences/Mûszaki és Menedzsment Tudományi Közlemények I/1.

[9] H. Moria, H. Chowdhury, F. Alam, A. Subic, (2010), Comparative aerodynamic analysis of commercial swimsuits, Sports Technology Vol. 3 , Iss. 4.

[10] D. Paár, (2013), A magyar háztartások sportfogyasztásának gazdasági szempontú vizsgálata, Doktori (PhD) értekezés, Nyugat-magyarországi Egyetem

[11] H. Preuss, (2015), Olimpia és gazdaság, Centrál Médiacsoport

[12] S. Reese, (2008) Today's Students, Tomorrow's Leaders, Techniques: Connecting Education and Careers (J1), v83 n1 pp 17-22.

[13] P. Róbert, (2001), Társadalmi mobilitás a tények és vélemények tükrében, Andorka Rudolf Társadalomtudományi Társaság Századvég

[14] S. Trangbaek, C. Rasmussen, T. B. Andersen, (2015), On the development of inexpensive speed and position tracking system for swimming, Sports Technology Vol. 8 , Iss. 1-2.

[15] 2004. évi I. törvény a sportról

[16] 65/2007. (VI. 27.) OGY határozat a Sport XXI. Nemzeti Sportstratégiáról

[17] Háttéranyag a sport XXI Nemzeti Sportstratégiához (2005) Összeállította: Molnár Anna, Dorgai Tímea (Letöltés: 2016.10.29.)

[18] 2015. évi XXXIII. törvény a Budapesten megrendezendő Úszó-, Vízilabda-, Múugró, Múúszó és Nyíltvízi Világbajnokság megvalósításához szükséges létesítményfejlesztésrő́l 451/2015. (XII. 28.) Korm. rendelet a Budapesten megrendezendő Úszó-, Vízilabda-, Müugró-, Műúszó és Nyíltvízi Világbajnokság megvalósításához szükséges egyes létesítmények építtetőjének kijelöléséről, valamint a toronyugrás céljából létesítendő óriás ugrótorony létesítését szolgáló ingatlanok meghatározásáról

[19] Budapest 2024 Nyári Olimpiai és Paralimpiai Játékok Megvalósíthatósági Tanulmány http://olimpia.hu/images/bp2024/PwC_Olimpiai\%20Megvalosithatosagi\%20tanulmany_ 2015_junius_vegleges.pdf (Letöltés: 2016. 10.31.)

[20] 1093/2017. (II. 22.) Korm. határozat a 2024. évi XXXIII. nyári olimpiai és XVII. nyári paralimpiai játékok rendezési jogáért kiírt pályázat helyzetéről

[21] Projekt összefoglaló, FINA 2017. évi Úszó-, Vízilabda-, Műugró, Múúszó és Nyíltvízi Világbajnokság, Budapest Főváros XIII. Kerületi Önkormányzat Képviselő-testületének ülése 2015.05.25.

[22] EUROBAROMETER (2014), Sport and Phisical Activity http://ec.europa.eu/public_opinion/archives/ebs/ebs_412_en.pdf (Letöltés: 2016.11.09.) 
[23] http://olimpia.hu/champdata/index/place/1/ (Letöltés: 2017.03.05.)

[24] http://www.nemzetisport.hu/sportnaptar/komjadi-bela-vilaghodito-poloforradalmar2068744 (Letöltés: 2017.03.05.)

[25] http://katinkahosszu.com/(Letöltés: 2016.12.29.)

[26] https://www.fina-budapest2017.com/ (Letöltés: többszöri 2016.09.01-2017.03.25-ig)

[27] http://masters.fina-budapest2017.com/hu (Letöltés: többszöri 2016.09.01-2017.03.09-ig)

[28] http://musz.hu/fajlok/adatbank/2017-01-14/8d216799_1_27_2017_01_08_musz_kgy hatarozatok_rendkivuli_kozgyules_2017_januar_8_.pdf (Letöltés: 2017. 03. 20.)

[29] https://hu.wikipedia.org/wiki/Hossz\%C3\%BA_Katinka(Letöltés: 2017.01.29.)

[30] http://www.nemzetisport.hu/uszas/vizes-vb-kazany-684-milliardos-nezettseggel-zart2440175 (Letöltés: 2016.12.26.)

[31] http://www.unesco.hu/kultura/vilagorokseg-www/vilagoroksegrol (Letöltés: 2016.12.27.)

[32] http://momebudapest.blogspot.hu/2016/09/market-ket-harom-honappal-elobb-keszul. html ( Letöltés: 2017.03.06.)

[33] http://musz.hu/hirek/ (Letöltés: 2017.03.06.)

[34] http://budapest.hu/Lapok/2016/interaktiv-latogatokozpontokban-mutatjak-be-abudapesti-olimpiai-palyazatot-es-a-jovo-nyari-vizes-vb-helyszineit.aspx

(Letöltés: 2016.11.01.)

[35] http://sportsci.unideb.hu/ (Letöltés: 2016.12.29.) 